\title{
Precision agriculture trends in fruit growing from 2016 to 2020
}

\author{
Lucas Molz Lara ${ }^{1}$, Luciano Gebler ${ }^{2}$, Mirabor José Leite Júnior ${ }^{3}$, Alencar Lucas Soares ${ }^{4}$
}

\begin{abstract}
Brazilian fruit culture has a great influence on the social and economic sector in the most diverse regions of the country, generating employment and income in the exercise of its activities. As it is an activity carried out most often in a manual and conventional manner, fruit culture has a great potential for technological growth, especially when adopting the concepts applied by precision agriculture on the crops of grains, fibers and energy, creating a new segment, Precision Fruit Farming. The present work aims to carry out a bibliographic review on the main trends that have emerged in the last five years on Precision Fruit growing, highlighting its future perspectives and the history of technological evolution. 83 articles were analyzed, classified in different perennial cultures and applications, such as machine learning, remote sensing, robotics, using UAV to obtain different vegetation indexes, among others.
\end{abstract}

Index Terms: Machine Learning; Vegetation Indexes; Robotics; Remote sensing; UAV.

\section{Tendências da agricultura de precisão em fruticultura no período de 2016 A 2020}

Corresponding author: luciano.gebler@embrapa.br

Received: July 27, 2020 Accepted: February 10, 2021

Copyright: All the contents of this journal, except where otherwise noted, is licensed under a Creative Commons Attribution License.
Resumo - A fruticultura brasileira exerce grande influência sobre o setor social e econômico nas mais diversas regiões do País, gerando emprego e renda no exercício de suas atividades. Por se tratar de uma atividade realizada, na maioria das vezes, de forma manual e convencional, a fruticultura possui grande potencial de crescimento tecnológico, principalmente ao adotar os conceitos aplicados pela agricultura de precisão sobre as culturas de grãos, fibras e energia, criando um novo segmento, a Fruticultura de Precisão. O presente estudo objetivou realizar uma revisão bibliográfica sobre as principais tendências que surgiram nos últimos cinco anos sobre a Fruticultura de Precisão, destacando suas perspectivas futuras e o histórico de evolução tecnológica. Foram analisados 83 artigos, classificados em diferentes culturas perenes e aplicações, como machine learning (aprendizado de máquinas), sensoriamento remoto, robótica, utilização de VANT para obtenção de diferentes índices de vegetação, entre outras.

Termos para indexação: Aprendizagem de Máquina; Índices de Vegetação; Robótica; Sensoriamento Remoto; VANT.

${ }^{1}$ Agronomist, Graduate student Precision Agriculture Master Program - PPGAP, Universidade Federal de Santa Maria, Santa Maria - RS, Brasil. E-mail: lmolzlara@gmail.com ${ }^{(0 R C I D}$ 0000-0002-7279-7181)

${ }^{2}$ Agronomist, PhD in Water Resources and Environmental Sanitation; Volunteer prof. Precision Agriculture Master Program - PPGAP/UFSM; Embrapa Uva e Vinho,Vacaria - RS, Brasil. E-mail:luciano.gebler@embrapa.br (ORCID 0000-0001-9622-5578)

${ }^{3}$ Agronomist, Graduate student Precision Agriculture Master Program - PPGAP, Universidade Federal de Santa Maria, Santa Maria - RS, Brasil.mirabor@outlook.com ${ }^{\text {(ORCID 0000-0003-3289-7687) }}$

${ }^{4}$ Geoprocessing Technologist; Graduate student Precision Agriculture Master Program - PPGAP, Universidade Federal de Santa Maria, Santa Maria - RS, Brasil. E-mail: alencar.soares4@gmail.com (ORCID 0000-0003-2308-5724) 


\section{Introduction}

In recent years, fruit production in Brazil has stood out as one of the main agricultural activities in the country, exerting great influence on the social and economic sector. The growing emphasis is linked to some important factors of the fruit scene, such as the generation of jobs and income in small areas and the high added value in its final product. In addition, Brazil has a wide variety of crops that adapt to the most diverse regions of the national territory.

According to the Brazilian Association of Producers and Exporters of Fruits and Derivatives (Abrafrutas), fruit production has more than 2.5 million hectares in all regions of the country. The production volume in 2018 reached 44 million tons and the sector employed $16 \%$ of the total agribusiness vacancies. This is because the activity has a high productivity in smaller areas, between 30 and 80 tons $\mathrm{ha}^{-1}$, while other crops such as soybean have a yield of 2.5 to 3.5 tons ha $^{-1}$ or corn, which reaches up to 12 to 15 tons $\mathrm{ha}^{-1}$. The study also states that for every 10 hectares destined for fruit production, around 25 people are employed, while for the cultivation of soybeans the same 10 hectares need only one collaborator (ABRAFRUTAS, 2018).

As a result of the potential of fruit growing in the Brazilian territory and its socioeconomic importance, it is necessary to adopt agricultural production systems based on the application of various cultural practices, optimized based on the use of available technologies. Depending on the culture or region of the country, the technological profile varies from medium to high, increasingly common among medium and large producers, and assists in carrying out production planning in an integrated and systemic manner, increasing production capacity, minimizing costs with the purchase of inputs, maximizing profits and maintaining environmental balance (LIU et al., 2006).

According to Bassoi et al. (2014) the systems currently used in fruit growing are characterized by the implementation of various agricultural practices during the crop cycle, with concern for the quality and quantity of production, given the possibility of serving both industry and direct sales to the consumer (GEBLER et al., 2015).

Therefore, an opportunity is created for the application of the modern techniques of Precision Agriculture as a way to improve the management of these systems regarding the use of management practices that take into account the differences between the quantitative and qualitative factors, presence or absence of biotic factors (pests and diseases), soil, plant and climate, which directly or indirectly influence production systems.

Precision Agriculture (PA) can be defined as a technique that makes intensive use of data to understand the variations of natural resources in an area, linked to the elements that affect production (SRINIVASAN, 2009).
The current scenario of PA is entirely linked to the cultivation of the main crops of grains, fibers, sugar cane and some perennial crops that focus their results only on gross productivity, such as coffee and oranges. However, its potential for use goes far beyond. Recently, fruit growing has adopted practices used by conventional PA, thus emerging a new term in the agricultural environment known as Precision Fruit Farming (PFG) (GEBLER et al., 2015), which can be described as a cycle that is repeated annually in perennial culture, from implantation to the eradication of plants in an area (Figure 1).

Because it is a recent activity and presents different particularities and needs in relation to conventional PA, PFG has been arousing the interest of research, which seeks pioneering solutions to the main challenges encountered in the sector, given that the focus on product quality becomes more relevant than productivity (GEBLER et al, 2015; ZUDE-SASSE et al., 2016). Thus, since even maintaining the basic logic of traditional PA, there is a need to incorporate extra factors in the collection, organization, data evaluation and decision making, always focusing on achieving the final goal of production with viable commercial profitability. Therefore, new trends in agriculture applied to the fruit environment have been discussed, such as the use of artificial intelligence algorithms from machine learning (machine learning), unmanned aerial vehicles (UAVs), computer vision and even robotics, mainly in highly demanding activities of labor, which are increasingly expensive and scarce.

The use of these techniques allows greater capture of the variations that occur in the cultivated areas, and may provide the implantation of a commercial cultivation system capable of reducing the variability of the intrinsic characteristics of the soil and the establishment of an adequate agricultural planning. In this way, areas with similar characteristics to each other receive the same set of agronomic practices and areas with differentiated behavior are endowed with a set of different practices.

However, unlike conventional PA, in most cases intensely mechanized and widespread in grain cultivation, Precision Fruit Farming lacks not only the use of qualified labor, but also the development of appropriate instruments and tools for the solution of more diverse situations found in the field, whenever linked to problems of spatial or temporal variability (ZUDE-SASSE et al., 2016). Therefore, the objective of this work is to carry out a bibliographic review on the main trends that emerged between the years 2016 and 2020 on Precision Fruit growing, highlighting its future perspectives and the history of technological evolution behind this activity so important for Brazil. 


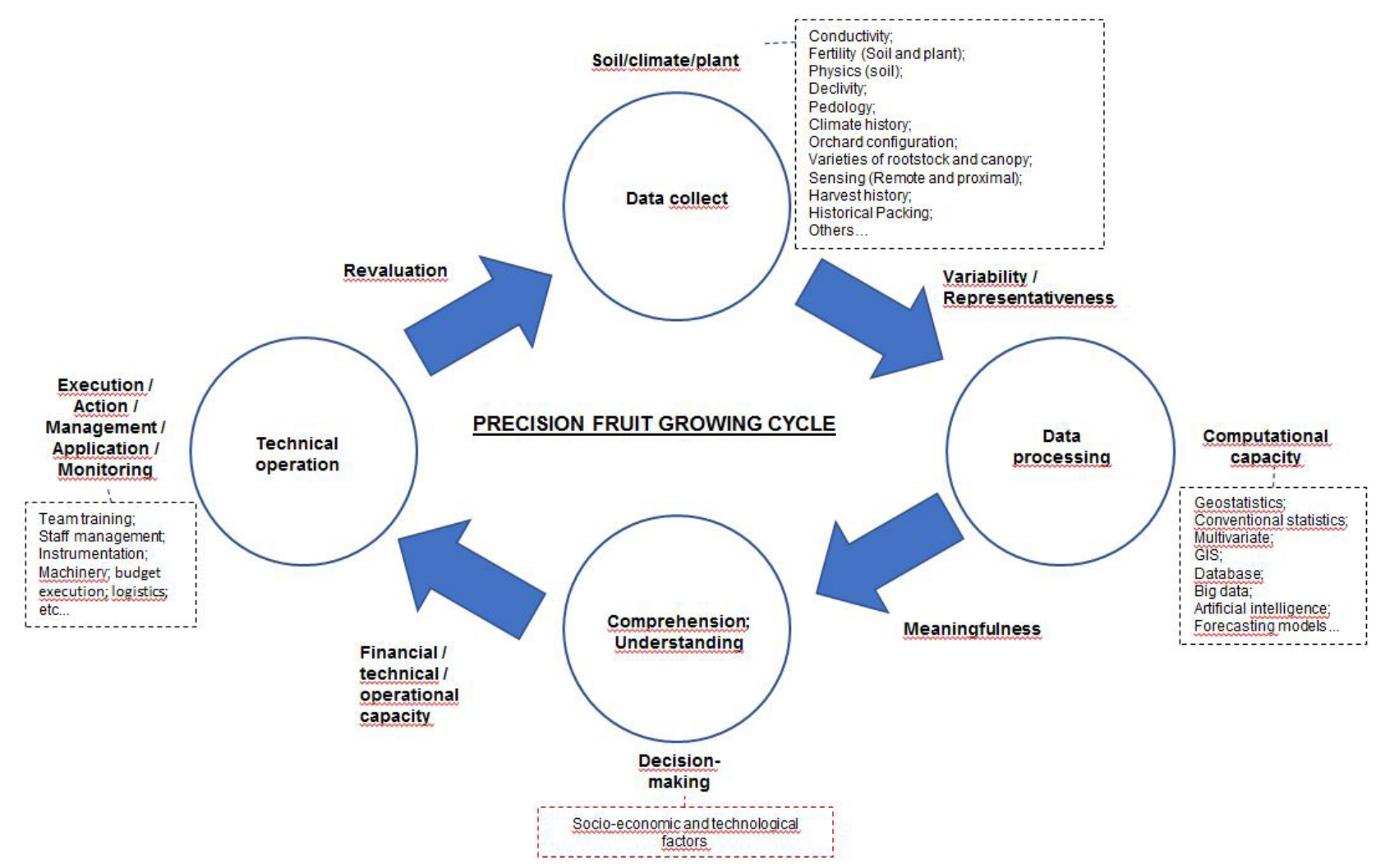

Figure 1. Use cycle of precision fruit growing.

\section{Recent technological developments in fruitculture}

From the development of the first studies on PFG, around the 2000s, and with the wide worldwide consumption of fruits, there was an expressive growth in the search for improvements in productivity and quality of fruit production with the help of technologies (devices and instruments) able to obtain information in real time (wind speed and direction, precipitation, air temperature and humidity, solar radiation, soil moisture, etc.), helping to optimize processes in different cultures. In this context, several technologies emerged to improve production, moving from manual or mechanical processes to an instrumentation phase, which was only possible due to the progressive development in the evolution of electronics.

Within the instrumentation dynamics in the area of crop mapping, several sensors linked to remote sensing have emerged, which record and capture the energy reflected by the elements of the earth's surface and generate data without physical contact with the culture, enabling the generation of various information. Depending on the characteristics presented, these sensors can be installed on terrestrial, aerial and orbital platforms (FLORENZANO, 2005), integrating data from other sources in order to generate assertive decision making for the producer. As a benefit, this contributed to the improvement in orchard management, the monitoring of work metrics, loss resolution, among others.
When using aerial digital images, information is collected using UAVs or orbital platforms (artificial satellites), generating vegetation indices that enhance spectral responses and facilitate correlation with other parameters, being able to support decision-making in the field. Rodrigues et al. (2017) compared and correlated the vegetation indices: NDVI (Normalized Difference Vegetation Index), GNDVI (Green Normalized Difference Vegetation Index), NDWI (Normalized Difference Water Index), MNDWI (Modified Normalized Difference Water Index) and the REP (Red Edge Position), with in situ data referring to soil fertility and mineral nutrition of plants in banana cultivation in the municipality of Lavras (MG). The results of their research were the GNDVI, which proved to be more suitable for this type of analysis.

In citrus, Abdulridha et al. (2019) tested 31 vegetation indices from images obtained by hyperspectral sensors coupled to a UAV, in order to verify which index had the best performance in the evaluation of citrus canker (Xanthomonas citri subsp. Citri) under laboratory and orchard conditions. As a result of the evaluation of the indices, the author concluded that the WI (Water Index), TCARI (Transform chlorophyll absorption in reflectance index) and ARI (Anthocyanin Reflectance Index) had better performances in detecting the disease. 
Rahman et al. (2018) correlated the canopy area of a mango orchard with 18 vegetation indexes obtained through high-resolution images from the WordView-3 satellite, to estimate productivity parameters in different mangroves (Mangifera indica). As the surveys were carried out in different orchards, the performance of the indexes varied, due to the difference in the age of the trees and management practices (irrigation, pruning, application of fertilizers, etc.), which influence the spectral characteristics (reflectance) of the canopy. The results obtained highlighted a better performance in some of the vegetation indexes tested in relation to others, with NDVI/ RED EDGE having a higher correlation for all mangroves.

A similar study was developed by Robson et al. (2017) seeking to measure the variability of the production of avocado (Persea americana) and macadamia (Macadamia integrifolia Maid. Et Bet.) Through remote sensing by satellite. An evaluation of 18 vegetation indexes (IVs), derived from WordView-3 images, was made. For macadamia, the IVs that performed the best determination coefficients for total walnut weight $(\mathrm{Kg}$ / tree) and the total number of walnuts per tree were RDVI1 (Red Edge Difference Vegetation Index 1) and N2RENDVI (Normalized difference Red Edge / NIR2 index ), while, for avocado, the best performances were N1GNDVI (Green Normalized Difference Vegetation / NIR1 Index, CB SIPI (Coastal Blue Structure Insensitive Pigment Index) and N1RENDVI (Normalized difference Red Edge / NIR1 index). the authors concluded that although there is a strong relationship between the spectral characteristics of the trees and the measured yield parameters, the determination of the optimal IV varies according to local factors and biotic and abiotic interferences.

The technological evolution of remote sensing in fruit growing continues to be developed and thrives mostly on Machine Learning techniques linked to high spatial and temporal resolution images, which offer new prospects for the identification and monitoring of plantations, allowing forecasts, disease monitoring and pests or crop monitoring based on real-time information (CALOU et al., 2019).

Gottschall et al. (2018) highlights in his work that the interpretation of sensor data and the generation of intelligent movement strategies in real time constitute one of the current challenges in controlling the programmed movement of robotic devices. Techniques based on the use of computer vision have been highlighted by the effectiveness presented in a non-destructive way to aspects related to the quality and control of fruits (BHARGAVA; BANSAL, 2018). Therefore, the use of artificial vision through the use of digital images is a potential demand to automate the inspection of fruits (SILVA et al., 2017).
Agriculture in general (grains, fruits and vegetables) is moving towards a scenario where the automation of processes and data science is already a reality, as this becomes the possibility of making adjustments in real time through alerts and / or warnings, act in a predictive manner, that is, understand some factor that may interfere in the field of production in advance and recognize patterns through groups of computer modeling approaches known as Machine Learning (ML), Deep Learning ( DL) and Artificial Intelligence (AI). But, in order to have the possibility of applying this science, it is essential to obtain data regarding the problem that is intended to be solved.

Calou et al. (2019) claim in their work that machine learning tools aligned to the remote sensing landscape have revolutionized data processing remotely, as one provides support for the other. Satellites, proximal sensors, UAVs and even terrestrial robots equipped with sensors developed for plant imaging (LiDAR, RGB, infrared, hyperspectral, thermal, fluorescent and 3D laser scanning) have provided high resolution images, which ends up resulting in difficulties in computational processing and in the generation of applicable information, due to the large volume captured, variety and speed of data input and the still relative lack of knowledge about when and which ones would be really needed to be monitored and which data and when they could be disregarded.

To solve this problem, the machine learning (ML) approach and algorithms that manipulate large amounts of data from the extraction of patterns and / or trends are applied, enabling the recognition of characteristics and supporting the four stages of decision in the target monitoring cycle: identification, classification, quantification and prediction (ICQP) (SINGH et al., 2016).

Recently, most of the work carried out in the field of precision fruit growing has focused on the inspection of phytosanitary problems caused by biotic and abiotic factors in plants and fruits, as well as to obtain advance information on the quantity of production, count of plants in the orchard, evaluation of canopy, identification of maturation, among others. For this, researchers are developing methodologies that use AI, ML and DP algorithms, thus being able to accurately classify and segment data from geoscience and remote sensing (CSILLIK et al., 2018).

Santos et al. (2020) developed machine learning methodologies, convolutional neural networks and Simultaneous Localization and Mapping (SLAM) techniques widely used in robotics to detect, segment and track grape clusters for wine. The authors achieved excellent results that enable the use of computer vision in photogrammetry and perceptual tasks, even in challenging environments such as agricultural orchards, where the variety of colors, sizes, shapes and structures are diverse. $\mathrm{He}$ also recommended the methodology for use in other perennial crops and with grape-like conduction systems, such as apple and peach orchards. 
In order to identify Esca disease (Stereum hirsutum and Polyporus igniarus) and golden flavescence (Flavescence dorée) on vine leaves quickly, nondestructively and with a good level of precision, Al-Saddik et al. (2018) used RGB and hyperspectral images to obtain spectral data from leaves. For the identification of patterns between infected and healthy leaves, the ML K-NN (K Nearest Neighbor) and SVM (Support Vector Machine) algorithms were used, reaching an overall accuracy of $99 \%$ when textural and spectral data were combined. Albertis et al. (2017) also sought to detect golden flavescence in vineyards, using multispectral images captured by a sensor embedded in UAV and algorithms to extract pixel patterns from the images and classify them into 4 classes: bare soil, shadows, vegetation between the lines and vegetation of the vines.

Calou et al. (2019), sought to identify and quantify yellow sigatoka in a commercial banana area through UAV images and application of supervised and grouping classification algorithms (Maximum Likelihood, Mahalanobis Distance, Minimum Distance, Neural Networks and Suport Vector Machine). It was observed that the Mahalanobis Distance cluster classification algorithm achieved better performances to identify ( $99.28 \%$ accuracy) and quantify the degree of severity of the pathogen.

Cheng et al. (2020) proposed a method for segmenting and evaluating treetops in Apple and Cherry orchards using Gaussian Mixture Models (GMMs) and the ML Extreme Gradient Boosting (XGBoost) algorithm. The GMM was used to segregate continuous trees and generate Gaussian standards to quantify the mixed cover resources, serving as training data for the XGBoos to assess the degree of mixing between the crowns.

This information corroborates for a conquest of space of artificial and robotic intelligence in the Brazilian and worldwide fruit scene, as these tools offer precise solutions to manage processes involving large volume of data and concomitant variables related to sowing, harvesting, weed control, supervision of orchards, chemical applications, etc.

According to Amer (2015), one of the main reasons for the development of automation in fruit growing is the reduction of costs and increased production efficiency, since it minimizes the need for specialized labor, generally the most expensive input in a system of fruit production. Other reasons are the need to improve food quality and safety, as well as automated fruit inspection.

Neto et al. (2019) relate the beginning of automation in fruit growing in Brazil with coffee crops, between the $50 \mathrm{~s}$ and $90 \mathrm{~s}$ and, more recently, at the end of the 20th century, on the harvest platforms in citrus. From there, there was a rapid evolution, moving from the simple mechanical automation phase to the instrumentation of monitoring processes and in precision agriculture, currently arriving in the development of autonomous vehicles. Since then, several companies have constantly sought to develop solutions to work with large volumes of production in an automated way.

In Europe, the importance of knowing the spatial variability in viticulture has led to the development of tools based on sensors embedded in autonomous vehicles, allowing quick and easy data collection, generating a large volume of information that contribute to the identification and solution of problems (LOPES et al., 2017).

It is important to keep in mind that the perennial plants, when not being replaced annually, accumulate impacts from uncontrolled factors over time (climatic, alternating production, anthropic, etc.), making the annual interventions planned to solve the problems end up generating only partial impacts in the short term and not those expected in full. This partial response ends up being distributed to the following years, potentiating the difference between the expected response and that obtained from the plants, making the relationship between the information collected by traditional methods of PA used in annual/biannual cultures and the responses expected by planning in perennial cultures unfeasible. In short, in the production phase in perennial foodstuffs, the time horizon has the capacity to redefine the impacts of planned interventions according to spatial variability on a recurring basis, including understanding the need for technical use of the biological crop instead of the economic crop or year agriculture (ZUDE-SASSE et al., 2016). This temporal variability has also been a developing environment for the application of mathematical modeling in the forecasting of scenarios, with the use of computational tools and the advancement of Artificial Intelligence.

It is important to note that robotics in agriculture is not a new concept. In greenhouses around the world, it has been present for at least the past three decades. According to Pavan (2012), research was carried out to develop harvesters for cherry tomatoes, cucumbers, mushrooms and other fruits. Still in fruit growing, robots are being evaluated or introduced to harvest citrus fruits and apples. Computers and robots control the process from the planting of the seedlings, to the cutting of the roots, packaging and weighing, and the product is free of any stain, disease or damage caused by insects.

Despite the emergence of prototypes capable of handling more delicate fruits, some fruit detection systems have yet to mature. The complexity of the natural environment of the orchards and the unstructured characteristics of the fruits bring great challenges for the identification of objects and location using robotics (BAC et al., 2014). 


\section{Methodology used in this review and its limits}

The following databases were used to prepare the research: CAPES Journal Portal, Scopus, Web of Science, Scholar Google, Multidisciplinary Digital Publishing Institute, Cellopress Selection, Elsevier, European Journal of Remote Sensing in order to search for updated data on Precision Fruit Growing and its innovations.

The terms used in the searches were: algorithms, artificial intelligence, machine learning, "BigData", computer vision, robotics, remote sensing, vegetation indexes and UAV. All terms accompanied the expression 'precision fruit growing' in order to refine the research to the central theme of this review. The imposed chronological limit limited the search to the last five years. Subsequently, the selection was made through titles, followed by objectives and, when selected, by a complete reading of the articles, obtaining a total of 83 publications at various levels (Articles in journals, abstracts in conference proceedings, technical communications, among others), gathered in the analyzed bibliography item, at the end of this review. Finally, each article was evaluated according to its degree of relevance, writing and relationship to the main theme of this review.

\section{RESULTS}

Disregarding the data from 2020 (collected until the end of the first quarter), it can be seen that from 2016 the production of articles focused on precision fruit growing doubled in volume and remained constant over the following three years (Figure 2)

Of the total, 42 works are Brazilian and 41 foreign, being classified in different cultures and applications. Of these published articles, some cultures stood out such as: Vine (22\%), Apple (10\%), Citrus (10\%), Banana (9\%), Mangueira (6\%), Coffee (5\%), Pereira (2\%), Papaya $(3 \%)$, Meloeiro (3\%), in addition to other fruits (Avocado, Pineapple, Cotton, Cherry, Lychee, Macadamia, Passion Fruit and Olive) with $10 \%$. Articles that did not involve any culture, but that somehow brought useful information about the application of tools in PFG in general, were also analyzed, being classified as general applications, reaching $20 \%$ of the total, as shown in Figure 3.

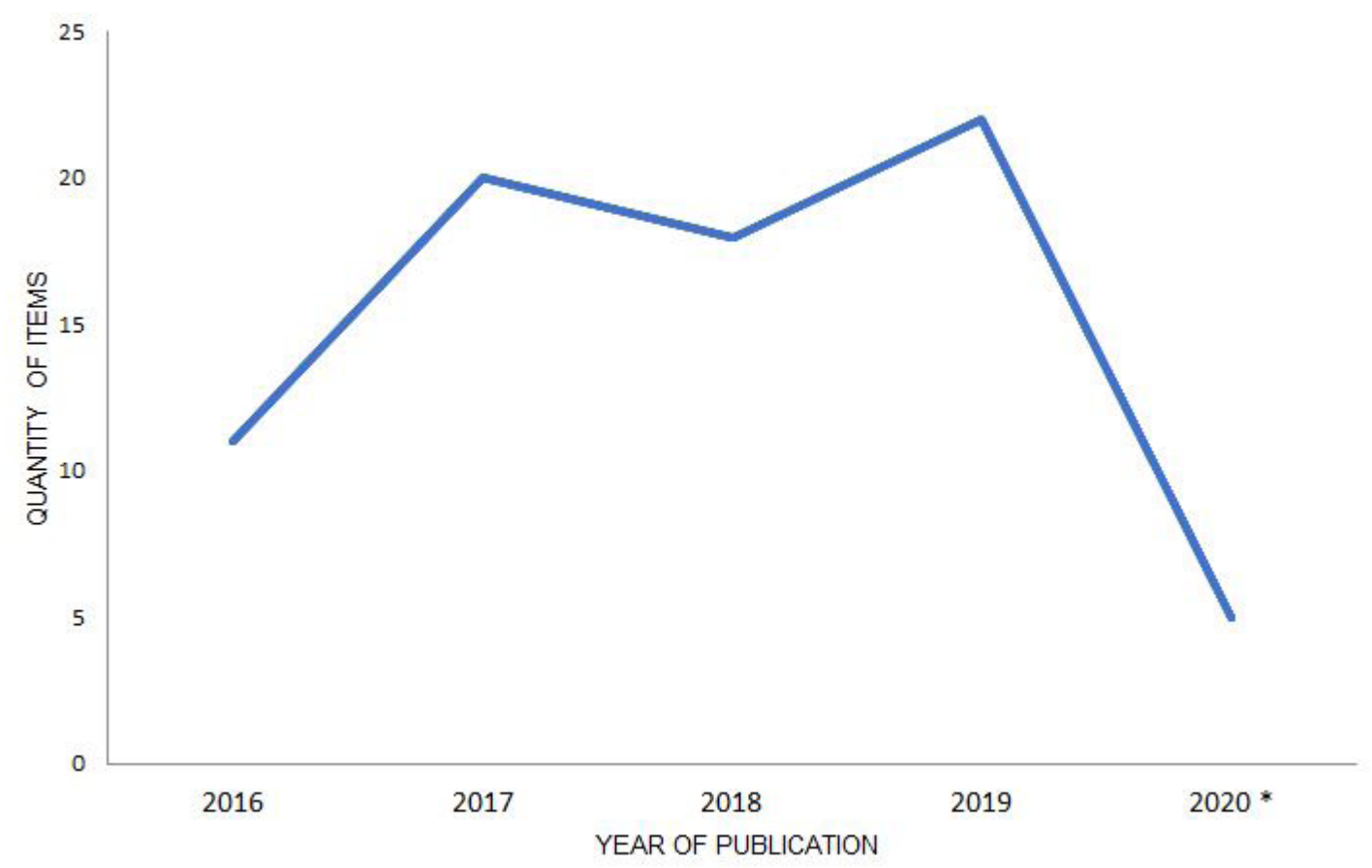

Figure 2. Number of publications between the years 2016 to $2020 *$ (* data collected until April). 


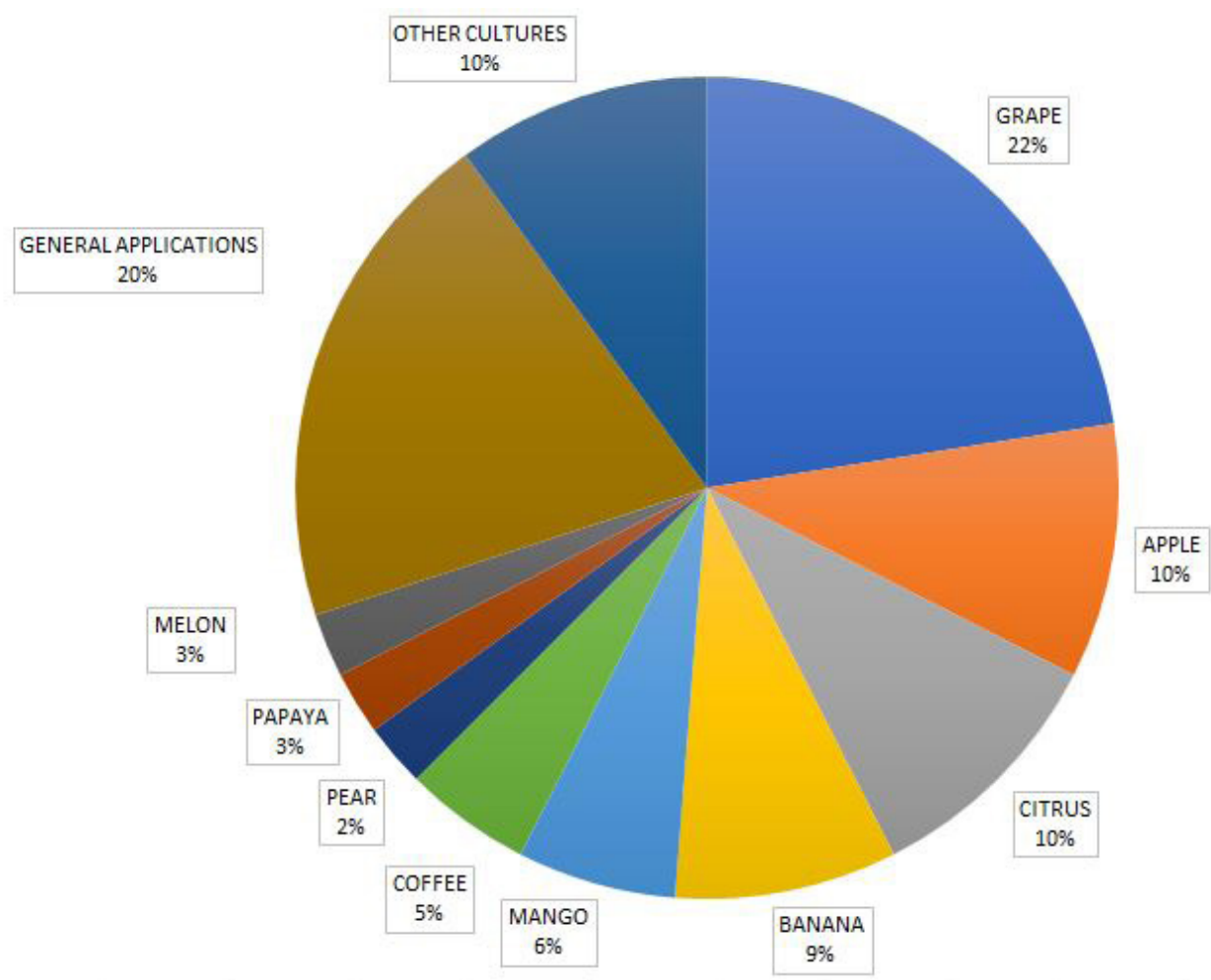

Figure 3. Themes and cultures cited in the articles and their percentage of participation in the total.

Therefore, an analysis was carried out by means of a triangulation of the main keywords, generating a quantitative index of the analyzed articles, which allowed to demonstrate the number of articles related to the subjects of most interest. The expressions' vegetation indexes' and 'remote sensing' stood out among the most frequently used keywords, followed by 'UAV', 'algorithms', 'image processing ',' machine learning ',' automation 'and' robotics', while more traditional ones, such as' GIS 'and' Variable rate 'have lost space for research importance in recent years (Figure 4).

According to Neto et al. (2019), carrying out a similar survey ended in 2015, the most relevant issues in previous years in precision fruit growing were strongly linked to aspects related to fertility and other aspects of the soil (electrical conductivity, fertility, varied rate, sample grid, among others), which were gradually eliminated from PFG research as they resulted in problem solving or proved not to be effective, being gradually replaced by remote monitoring, instrumentation, robotics or system data processing. This also resonates with the advancement of hardware and software systems available today, due to the lower costs and miniaturization of sensors and hardware available on the market.

Crossing the data of the analyzed cultures and the keywords used in the articles, it was noted that the subjects that stood out the most today are focused on apple, viticulture and citrus crops (Figure 5).

There is a justification, based on the age of PFG research and the importance of culture in the market for the behavior of the data collected and presented in figure 5 .
Historically, the culture of the vine was one of the pioneers in studies involving precision agriculture due to irrigation and automation, both in California and Australia (BASSOI et al., 2014; NETO et al., 2019). In addition, the grapevine, along with apple and citrus, are presented as some of the main perennial food crops in terms of marketing volume in the world.

In the other cultures listed in figure 5 , the texts refer to the degree of importance (Economic, social, etc.) given to the respective local perennial food species. This again explains the reason for the delay in precision fruit growing in relation to traditional PA, the specific regionalization of each perennial food culture, with problems and solutions based on its own local and temporal variability, with great difficulty in replicating for other agricultural situations, different from observed in traditional agricultural commodities.

It is important to note that the demand for technologies in Precision Fruit Growing has increased considerably in recent years, however, it is still in full expansion and evolution. In addition, during the analysis and collection of keywords represented in figure 4, it was possible to notice the increase in relevance and prominence in matters related to the area of software and instrumentation in detriment to the development of heavy machines (linked to the application at a varied rate), such as artificial intelligence, machine learning, robotics, remote sensing, use of UAVs and sensors to obtain different vegetation indexes or monitoring. 


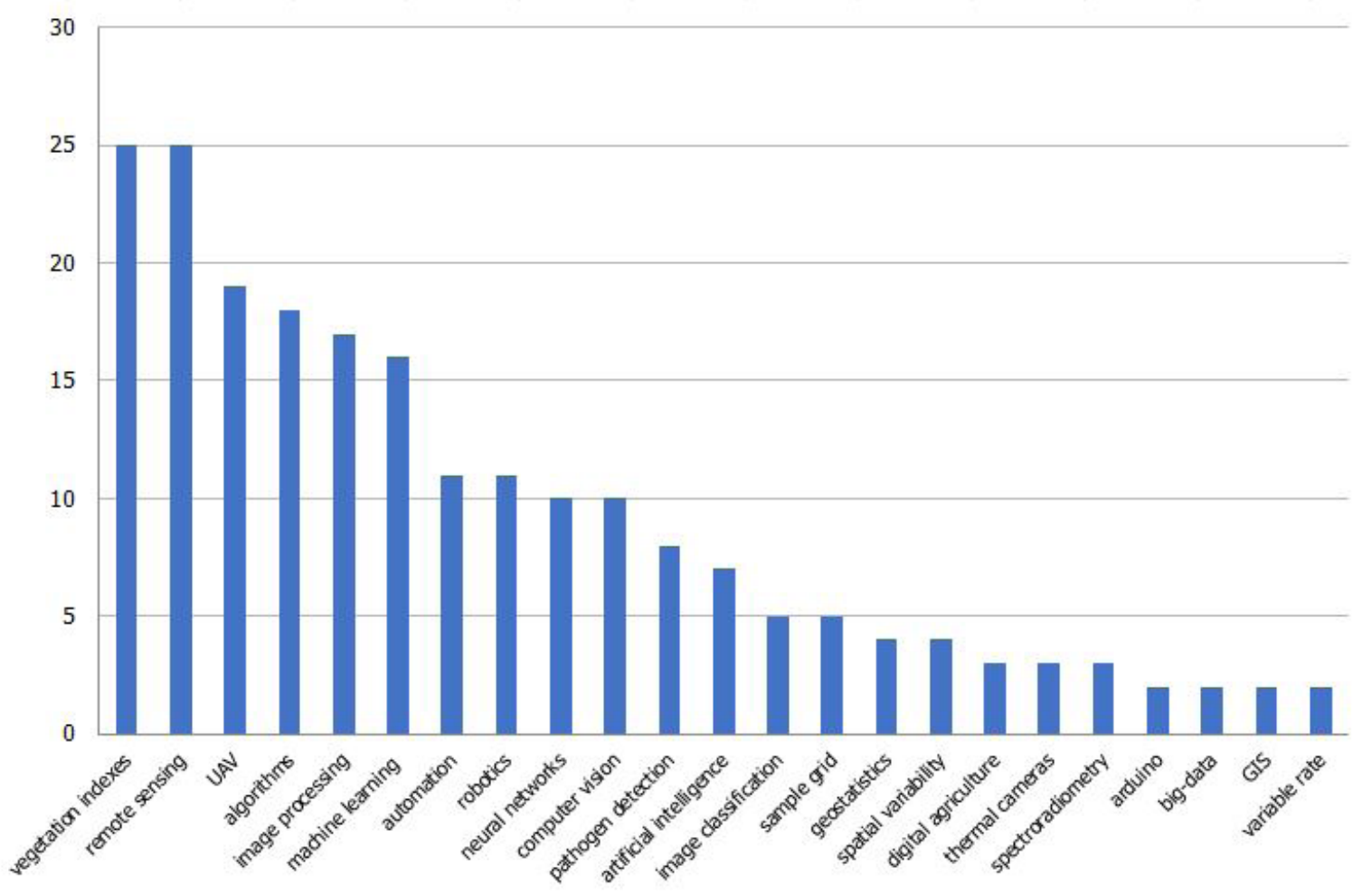

Figure 4. Quantitative graph of incidence of the main keywords used in publications.

\begin{tabular}{|c|c|c|c|c|c|c|c|c|c|}
\hline algorithms & & & & & & & & & \\
\hline \multicolumn{10}{|l|}{ machine learning } \\
\hline \multicolumn{10}{|l|}{ automation } \\
\hline \multicolumn{10}{|l|}{ thermal cameras } \\
\hline \multicolumn{10}{|l|}{ image classification } \\
\hline \multicolumn{10}{|c|}{ pathogen detection } \\
\hline \multicolumn{10}{|c|}{ spectroradiometry } \\
\hline \multicolumn{10}{|l|}{ geostatistics } \\
\hline \multicolumn{10}{|l|}{ sample grid } \\
\hline \multicolumn{10}{|c|}{ vegetation indexes } \\
\hline \multicolumn{10}{|c|}{ artificial intelligence } \\
\hline \multicolumn{10}{|l|}{ image processing } \\
\hline \multicolumn{10}{|l|}{ neural networks } \\
\hline \multicolumn{10}{|l|}{ robotics } \\
\hline \multicolumn{10}{|l|}{ remote sensing } \\
\hline \multicolumn{10}{|l|}{ GIS } \\
\hline \multicolumn{10}{|l|}{ variable rate } \\
\hline \multicolumn{10}{|l|}{ UAV } \\
\hline \multicolumn{10}{|l|}{ spatial variability } \\
\hline \multicolumn{10}{|l|}{ computer vision } \\
\hline & GRAPE & APPLE & CITRUS & BANANA & MANGO & COFFEE & MELON & PEAR & PAPAYA \\
\hline
\end{tabular}

Figure 5. Relationship between the cultures mentioned in the publications and the themes attributed by the keywords. 


\section{Final considerations}

In view of the above, it is important to note that currently the main trends and future perspectives for Precision Fruit Farming are focused on the study of methods and techniques for learning machines and the evolution and development of robotics in fruit growing, notably due to the concern with costs availability of labor.

It was also noted that studies in the areas linked to remote sensing and aimed at the analysis of vegetation indexes with the aid of images from Unmanned Aerial Vehicles (UAVs) and artificial satellites, are still in constant development in the area of Precision Fruit, demanding further studies for its establishment as an established methodology.

The areas traditionally seen in conventional precision agriculture such as fertility, weed control or soil mapping have not shown the same importance in precision fruit growing in recent years.

\section{References}

ABDULRIDHA, J.; BATUMAN, O.; AMPATZIDIS, Y. UAV-based remote sensing technique to detect citrus canker disease utilizing hyperspectral imaging and machine learning. Remote Sensing, Washington, v.11, n.11, p.1373, 2019.

ABRAFRUTAS. Fruticultura. Setor em expansão. Brasília, 2018. Disponível em: https://abrafrutas. org/2018/08/14/fruticultura-setor-em-expansão/. Acesso em: 05 jun. 2020.

Albetis, J.; DUthoit, S.; GUTTLER, F.; JACQUIN, A.; GOULARD, M.; POILVÉ, H.; DEDIEU, G.MAGALHÃES, L.P.DE; BRICHI, L.; GOMES, T.M.; ROSSI, F. Detection of Flavescence dorée grapevine disease using unmanned aerial vehicle (UAV) multispectral imagery. Remote Sensing, Washington, v.9, n.4, p.308, 2017.

AL-HIARY, H.; BANI-AHMAD, S.; REYALAT, M.; BRAIK, M.; ALRAHAMNEH, Z. Fast and accurate detection and classification of plant diseases. International Journal of Computer Applications, London, v.17, n.1, p.31-38, 2012.

AL-SADDIK, H.; LAYBROS, A.; BILLIOT, B.; COINTAULT, F. Using image texture and spectral reflectance analysis to detect Yellowness and Esca in grapevines at leaf-level. Remote Sensing, Washington, v.10, n.4, p.618, 2018.
ALVES, H .M.R.; INÁCIO, F.D.; VOLPATO, M.M.; VIEIRA, T.G.; DANTAS, M.F.; CAMPOS, B.F.; LOGATO, E.S. Caracterização e distribuição espacial dos ambientes cafeeiros de Minas Gerais. In: SIMPÓSIO BRASILEIRO DE SENSORIAMEYNTO REMOTO, 19., 2019, Santos. Anais [...], São José dos Campos: INPE, 2020.

AMER, G.; MUDASSIR, S.M.M.; MALIK, M.A. Design and operation of Wi-Fi agribot integrated system. In: INTERNATIONAL CONFERENCE ON INDUSTRIAL INSTRUMENTATION AND CONTROL (ICIC), 2015. Pune. Proceedings [...] Pune: IEEE, p.207-212, 2015.

ARIVAZHAGAN, S.; SHEBIAH, R.N.; ANANTHI, S.; VARTHINI, S.V. Detection of unhealthy region of plant leaves and classification of plant leaf diseases using texture features. Agricultural Engineering International: CIGR Journal, Paris, v.15, n.1, p.211-217, 2013.

ARRUDA, S.; SILVEIRA, K.B.V.; MUNIEWEG, R.A.; MEUS, E.N. Uma nova perspectiva para produção de hortaliças sustentável: robô com sensores para medir variáveis ambientais. Anais Do Salão Internacional De Ensino, Pesquisa E Extensão, Bagé, v.8, n.2, 2017.

BAC, C.W.; VAN HENTEN, E.J.; HEMMING, J.; EDAN, Y. Harvesting robots for high value crops: State of the art review and challenges ahead. Journal of Field Robotics, New York, v.31, n.6, p.888-911, 2014.

BALLESTEROS, R.; ORTEGA, J.F.; HERNANDEZ, D.; MORENO, M.A. Characterization of Vitis vinifera L. canopy using unmanned aerial vehicle-based remote sensing and photogrammetry techniques. American Journal of Enology and Viticulture, Davis, v.66, n.2, p.120-129, 2016.

BASSOI, L.H.; MIELE, A.; REISSER JUNIOR, C.; GEBLER, L.; FLORES, C.A.; FILIPPINI ALBA, J.M.; GREGO, C.R.; TERRA, V.S.S.; TIMM, L.C.; NASCIMENTO, P.dos S. Agricultura de precisão em fruticultura. In: BERNARDI, A.C.C.; NAIME, J.M.; RESENDE, A.V.de; BASSOI, L.H.; INAMASU, R.Y. (ed.). Agricultura de precisão: resultados de um novo olhar. Brasília, DF: Embrapa, p.350-360, 2014.

BATISTA, A.V.D.A.; ALBIERO, D.; VIANA, T.V.D.A.; MONTEIRO, L.D.A.; CHIODEROLI, C.A.; SOUSA, I.R.S.D.; AZEVEDO, B.M. Multifunctional robot at low cost for small farms. Ciência Rural, Santa Maria, v.47, n.7, 2017. 
BELLO, T.B.; COSTA, A.G.; DA SILVA, T.R.; PAES, J.L; OLIVEIRA, M.V.M. de. Classificação de frutos de tomates em diferentes estádios de maturação por meio das variáveis colorimétricas. In: CONGRESSO BRASILEIRO DE ENGENHARIAAGRÍCOLA - CONBEA, 48., 2019. Campinas, Anais [...] Jaboticabal: SBEA, 2019.

BERTOL, I.; BERTOL, C.; BARBOSA, F.T. Simulador de chuva tipo empuxo com braços movidos hidraulicamente: fabricação e calibração. Revista Brasileira de Ciência do Solo, Viçosa, MG, v.36, n.6, p.1905-1910, 2012.

BHARGAVA, A.; BANSAL, A. Fruits and vegetables quality evaluation using computer vision: A review. Journal of King Saud University-Computer and Information Sciences, Riyadh, 2018. Available from: https://doi.org/10.1016/j.jksuci.2018.06.002

BUENO, M.E.B.; RUFATO, L.; GEBLER, L. Técnicas de sensoriamento remoto na cultura da macieira. In: CONGRESSO BRASILEIRO DE ENGENHARIA AGRÍCOLA, 44., 2015. São Pedro. Anais [...]. São Paulo: CONBEA, 2015.

CALIMAN, C.D.S.; CARDOSO, A.; VENTURA, J.; da COSTA, V.M.; PAVAN, J.; de Castro, H.C.J.V.; CAETANO, L. Tamanho de amostra para avaliar características de banana. Revista Científica Intelletto, Santa Cruz, v.4, n.2, p.96-104, 2019.

CALOU, V.B.C.; TEIXEIRA A. dos S.; MOREIRA, L.C.J.; OLIVEIRA, J. de B.; LIMA, C.S.; ROCHA, M.O. Uso de algoritmos de classificação para identificação da Sigatoka-amarela através de imagens de VANT. In: SIMPÓSIO BRASILEIRO DE SENSORIAMENTO REMOTO, 19., 2019, Santos. Anais [...]. São José dos Campos: INPE, 2020.

CALOU, V.B.C.; TEIXEIRA, A.S.; MOREIRA, L.C.J.; OLIVEIRA, J.B.; LIMA, C.S.; QUEIROZ, T.R.G. Quantificação de doença foliar da bananeira utilizando índices RGB em imagens de RPA. In: CONGRESSO BRASILEIRO DE ENGENHARIA AGRÍCOLA CONBEA, 48., 2019. Campinas, Anais [...] Jaboticabal: SBEA, 2019.

CANTELLI, L.; BONACCORSO, F.; LONGO, D.; MELITA, C.D.; SCHILlACI, G.; MUSCATO, G. A small versatile electrical robot for autonomous spraying in agriculture. AgriEngineering, Basel, v.1, n.3, p.391$402,2019$.
CHENG, Z.; Qi, L.; CHENG, Y.; Wu, Y.; ZHANG, H. Interlacing orchard canopy separation and assessment using UAV images. Remote Sensing, Washington, v.12, n.5, p.767, 2020.

COLAÇO, A.F.; MOLIN, J.P.; ROSELL-POLO, J.R. Spatial variability in commercial orange groves. Part 1: canopy volume and height. Precision Agriculture, Boston, v.20, n.4, p.788-804, 2019.

COLAÇO, A.F.; MOLIN, J.P.; ROSELL-POLO, J.R. Spatial variability in commercial orange groves. Part 2: relating canopy geometry to soil attributes and historical yield. Precision Agriculture, Boston, v.20, n.4, p.805822, 2019.

COLAÇO, A.F.; TREVISAN, R.G.; MOLIN, J.P.; ROSELL POLO, J.R. Orange tree canopy volume estimation by manual and LiDAR-based methods. Advances in Animal Biosciences, Cambridge, v.8, n.2, p.477-480, 2017.

CORDEIRO, B.; BAZZI, C.L.; GEBLER, L.; SILVA, F.D. Dispositivo de coleta e armazenamento de dados de colheitas manuais em pomares para geração de mapas de produtividade. In: CONGRESSO BRASILEIRO DE FRUICUlTURA, 28., 2019, Petrolina. Anais [...]. Petrolina: EMBRAPA: UFVSF, p.2418-2421, 2019.

CRUVINEL, PAULO E. Gerenciamento de risco decorrente de doenças fúngicas em cultura da banana baseado em automação e aprendizado de máquinas. In: CONGRESSO BRASILEIRO DE ENGENHARIA AGRÍCOLA - CONBEA, 48., 2019. Campinas, Anais [...] Jaboticabal: SBEA, 2019.

CSILLIK, O.; CHERBINI, J.; JOHNSON, R.; LYONS, A.; KELLY, M. Identification of citrus trees from unmanned aerial vehicle imagery using convolutional neural networks. Drones, Basel, v.2, n.4, p.39, 2018.

DA SILVA ERTHAL, G.M.; RUSSINI, A.; SEBEM, E.; ERTHAL, E.S.; GALAFASSI, C. Diagnóstico da adoção da viticultura de precisão no vale dos vinhedos - Rio Grande do Sul. Tecno-Lógica, Santa Cruz do Sul, v.22, n.2, p.174-186, 2018.

DE ALMEIDA, C.O.; REINHARDT, D.; OLIVEIRA, A.; GERUM, A.D.A.; SOUZA, J.D.S. Demandas tecnológicas do setor produtivo da fruticultura baiana. In: CONGRESSO BRASILEIRO DE FRUTICULTURA, 26., 2019, Juazeiro. Anais [...]. Petrolina: Embrapa Semiárido, 2019. 
DIAS, R.D.S.; SILVA, S.D.O.; LEDO, C.D.S.; RIBAS, R.F. Índice de vegetação por diferença normalizada em mamoeiro. In: CONGRESSO BRASILEIRO DE FRUTICULTURA, 26., 2019, Juazeiro. Anais [...]. Petrolina: Embrapa Semiárido, 2019.

DONG, X.; ZHANG, Z.; YU, R., TIAN, Q.; ZHU, X. Extraction of information about individual trees from high-spatial-resolution UAV-acquired images of an orchard. Remote Sensing, Washington, v.12, n.1, p.133, 2020 .

DOS SANTOS, F.N.; SOBREIRA, H.; CAMPOS, D.; MORAIS, R.; MOREIRA, A.P.; CONTENTE, O. Towards a reliable robot for steep slope vineyards monitoring. Journal of Intelligent \& Robotic Systems, Dordrecht, v.83, n.3-4, p.429-444, 2016.

ESPINOZA, C.Z.; KHOT, L.R.; SANKARAN, S.; JACOBY, P.W.High resolution multispectral and thermal remote sensing-based water stress assessment in subsurface irrigated grapevines. Remote Sensing, Washington, v.9, n.9, p.961, 2017.

FILIPPINI ALBA, J.M.; DO AMARAL, M.T.; GEBLER, L. Potencial da agricultura de precisão para aprimorar a produção de maçã no Rio Grande do Sul. Brasília, DF: Embrapa Clima Temperado, 2017. (Documentos)

FLORENZANO, T.G. Geotecnologias na geografia aplicada: difusão e acesso. Revista do Departamento de Geografia, São Paulo, n.17, p.24-29, 2005.

FRIGERI, J.V. Avaliação de metodologia para inventário de uva-do-Japão (Hoveniadulcis Thunb.) utilizando imagens de veículos aéreos não tripulados (VANT) na UTFPR -campus Dois Vizinhos. 2016. Monografia (Trabalho de Conclusão de Curso) Universidade Tecnológica Federal do Paraná, Curitiba.

GAUR, N.; MOHANTY, B.P.; KEFAUVER, S.C. Effect of observation scale on remote sensing-based estimates of evapotranspiration in a semi-arid row cropped orchard environment. Precision Agriculture, Boston, v.18, n.5, p.762-778, 2017.

GEBLER, L.; GREGO, C.R.; VIEIRA, A.L.; KUSE, L.R. Spatial influence of physical and chemical parameters on management zone definition in apple orchards. Engenharia Agrícola, Jaboticabal, v.35, p.1160-1171, 2015.
GEBLER, L.; LONGO, D.R.; MOREIRA, G.C.; BAZZI, C.L.; SCHENATTO, K.Appleshow: sistema de informação geográfica (SIG) de baixo custo para geração de mapas para a cultura da macieira. In: ENCONTRO NACIONAL SOBRE FRUTICULTURA DE CLIMA TEMPERADO, 16., 2019, Fraiburgo. Anais [...]. Fraiburgo: Epagri, p.134, 2019.

GENÉ-MOLA, J.; GREGORIO, E.; GUEVARA, J.; AUAT, F.; SANZ-CORTIELLA, R.; ESCOLÀ, A.; ROSELL-POLO, J.R. Fruit detection in an apple orchard using a mobile terrestrial laser scanner. Biosystems Engineering, London, v.187, p.171-184, 2019.

GOTTSCHALL, C.R. de A; LIMA, D.S.; MARQUES, J.E.S.; AMADO, J.A.D.; LIBARINO C.S. Seleção de qualidade de frutas do tipo manga utilizando visão computacional com redes neurais aplicada a um processo de manufatura robotizada. In: MOSTRA NACIONAL DE ROBÓTICA - MNR, 8., 2018, João Pessoa. Anais [...] Sorocaba: MNRM, 2018.

GOTTSCHALL, C.R.de A; MARQUES, J.E.S.; LIBARINO C.S; AMADO, J.A.D. Sistema de manufatura inteligente para seleção de mangas utilizando deep learning. In: SIMPÓSIO BRASILEIRO DE AUTOMAÇÃO INTEligenTE, 14., 2019, Ouro Preto. Anais [...]. Campinas: Galoá, 2020.

HOFF, R; BERGMANN, M; ALBERTI, R.Geologia integrada a dados de relevo para caracterização de terroir vitivinícola em Pinheiro Machado, Brasil. In: SIMPÓSIO BRASILEIRO DE SENSORIAMENTO REMOTO, 2017, Santos. Anais [...]. São José dos Campos: INPE, p.6391$6398,2020$.

HOSKEN R.; MARCATTI, G.E.Detecção de anomalias na cultura do café utilizando imagens do satélite Sentinel-2. In: SIMPÓSIO BRASILEIRO DE SENSORIAMENTO REMOTO, 2017, Santos. Anais [...]. São José dos Campos: INPE, 2017.

JOHANSEN, K.; RAHARJO, T.; MCCABE, M.F.Using multi-spectral UAV imagery to extract tree crop structural properties and assess pruning effects. Remote Sensing, Washington, v.10, n.6, p.854, 2018.

JUNGES, A.H.; ALMANÇA, M.A.K.; DUCATI, J.R.; LAMPUGNANI, C.S.Espectrorradiometria para detecção de alterações na assinatura espectral de folhas de videiras por doenças de causa fúngica e viral. In: SIMPÓSIO BRASILEIRO DE SENSORIAMENTO REMOTO, 2017, Santos. Anais [...]. São José dos Campos: INPE, 2017. 
JUNGES, A.H.; FONTANA, D.C.; ANZANELLO, R.; BREMM, C. Normalized difference vegetation index obtained by ground-based remote sensing to characterize vine cycle in Rio Grande do Sul, Brazil. Ciência e Agrotecnologia, Lavras, v.41, n.5, p.543-553, 2017.

JUNGES, A.H.; PAULETTO, H.; HOFF, R.; DUCATI, J.R.; ALBERTI, R. Imagens Landsat para monitoramento de vinhedo na região da Campanha Gaúcha por perfil temporal de NDVI . In: SIMPÓSIO BRASILEIRO DE SENSORIAMENTO REMOTO, 2017, Santos. Anais [...]. São José dos Campos: INPE, 2017.

LACERDA, E.DAS G.; SCHIMILDT, D.S.; SILVESTRE, N.G.; MATOS, W.T.; OLIVEIRA, E.M.DE. Avaliação do uso de técnicas de interpolação para estimativa de $\mathrm{k}$ e pH do solo em área de citricultura. In: CONGRESSO BRASILEIRO DE ENGENHARIA AGRÍCOLA CONBEA, 46., 2017, Maceió. Anais [...] Jaboticabal: SBEA, 2017.

LIU, T.L.; JUANG, K.W.; LEE, D.Y. Interpolating soil properties using kriging combined with categorical information of soil maps. Soil Science Society of America Journal, Madison, v.70, n.4, p.1200-1209, 2006.

LOPES, C.M.; GRAÇA, J.; VICTORINO, G.; GUZMÁN, R.; TORRES, A.; REYES, M.; MONTEIRO, A. VINBOT - um robô terrestre para viticultura de precisão. In: CONGRESSO LUSO-BRASILEIRO DE HORTICULTURA| SESSÃO VITICULTURA, 1., 2017, Lisboa. Actas [...]. Lisboa: ISA, 2017, p.517-523.

MACHOVINA, B.L.; FEELEY, K.J.; MACHOVINA, B.J. UAV remote sensing of spatial variation in banana production. Crop and Pasture Science, Adelaide, v.67, n.12, p.1281-1287, 2017.

MAGALHÃES, L.P.DE; BRICHI, L.; GOMES, T.M.; ROSSI, F. Índices vegetativos para detecção de deficiência de fósforo em tomateiro. In: CONGRESSO BRASILEIRO DE ENGENHARIAAGRÍCOLA - CONBEA, 46., 2017, Maceió. Anais [...] Jaboticabal: SBEA, 2017.

MEYERS, J.M.; DOKOOZLIAN, N.; RYAN, C.; BIONI, C.; VANDEN HEUVEL, J.E.ANew, satellite NDVIbased sampling protocol for grape maturation monitoring. Remote Sensing, Washington, v.12, p.1159, 2020.
NETO, D. de O.; SAMPAIO, M.I.R.; VEREIRO, R.B.; ZAMBERLAN, J.F.; GEBLER, L.; AMARAL, L. de P. Automação da fruticultura de precisão no Brasil: uma revisão. In: CONGRESSO SULAMERICANO DE AGRICULTURA DE PRECISÃO E MÁQUINAS PRECISAS, 5., 2019. Anais [...], Não-Me-Toque: Prefeitura Municipal de Não-Me-Toque, p.652-661, 2019.

NHAMO, L.; VAN DIJK, R.; MAGIDI, J.; WIBERG, D.; TSHIKOLOMO, K. Improving the accuracy of remotely sensed irrigated areas using post-classification enhancement through UAV capability. Remote Sensing, Washington, v.10, n.5, p.712, 2018.

NOORI, O.; PANDA, S.S. Site-specific management of common olive: remote sensing, geospatial, and advanced image processing applications. Computers and Electronics in Agriculture, Amsterdam, v.127, p.680- 689, 2016.

OLIVEIRA, C.J.D; MENDES L.G.; COLAÇO, A.F.; MOLIN, J.P. Balanço de nutrientes na adubação a taxas variáveis em pomares de 2 citros. In: CONGRESSO BRASILEIRO DE AGRICULTURA DE PRECISÃO ConBAP, 2018, Curitiba. Anais [...]. Piracicaba: AsBraAP , 2018.

PAULETTO, H.; HOFF, R.; HEMAN, L.; NHOATTO, M.; ALBERTI, R.Investigação do ciclo de pomares de macieira pelo NDVI de imagens sentinel-2 na região dos Campos de Cima da Serra, Rio Grande do Sul, Brasil. In: SIMPÓSIO BRASILEIRO DE SENSORIAMENTO REMOTO, 19., 2019, Santos. Anais [...]. São José dos Campos: INPE, p.2188-2191, 2020.

PAVAN, C.; SIVAKUMAR, D.B. Wi-Fi Robot for video monitoring \& surveillance system. International Journal of Scientific \& Engineering Research, Hilla, v.3, n.8, p.1, 2012.

PEÇANHA, D.; FREITAS, M.; NEVES, D.D.A.; PINTO, L.; DOS SANTOS, P.C.; de CARVALHO, A.J.C.; VIEIRA, M. Índice SPAD em abacaxizeiro Vitória sob deficiência nutricional. In: ENCONTRO BRASILEIRO DE HIDROPONIA, 12.; SIMPOSIO BRASILEIRO DE HIDROPONIA, 4., 2018. Santa Catarina. Anais [...]. Florianópolis: UFSC, 2018. 
PITHAN, P.A.; DUCATI, J.R.; GARRIDO, L.; DE ARRUDA, D.; BORTOLOTTO, V.; THUM, A.; DOS SANTOS, M.A.G. Sensoriamento remoto hiperespectral aplicado na discriminação de doenças fúngicas da videira. In: SIMPÓSIO BRASILEIRO DE SENSORIAMENTO REMOTO, 2017, Santos. Anais [...]. São José dos Campos: INPE, 2020.

QUEIROZ, T.R.G.; OLIVEIRA, M.R.R.; MOREIRA, L.C.J.; TEIXEIRA, A.S.; ROCHA, M.O.; CALOU, V.B.C.; CASTELO BRANCO, A.L.C.Uso de imagens de VANT'S para estimar a distribuição espacial do índice SPAD em dossel de meloeiro. In: SIMPÓSIO BRASILEIRO DE SENSORIAMENTO REMOTO, 2017, Santos. Anais [...]. São José dos Campos: INPE, 2020.

RAHMAN, M.M.; ROBSON, A.; BRISTOW, M. Exploring the potential of high-resolution worldview-3 Imagery for estimating yield of mango. Remote Sensing, Washington, v.10, n.12, p.1866, 2018.

ROBSON, A.; RAHMAN, M.M.; MUIR, J.; SAINT, A.; SIMPSON, C.; SEARLE, C. Evaluating satellite remote sensing as a method for measuring yield variability in Avocado and Macadamia tree crops. Advances in Animal Biosciences, Cambridge, v.8, n.1, p.498-504, 2017.

RODRIGUES, J.D.P.; CARVALHO ALVES, M. de; DE FREITAS, A.S.; POZZA, E.A. Análise espectral orbital da sigatoka-amarela da bananeira e sua relação com a nutrição mineral do solo e das plantas. In: SIMPÓSIO BRASILEIRO DE SENSORIAMENTO REMOTO, 2017, Santos. Anais [...]. São José dos Campos: INPE, 2017.

SA, I.; GE, Z.; DAYOUB, F.; UPCROFT, B.; PEREZ, T.; MCCOOL, C. Deepfruits: a fruit detection system using deep neural networks. Sensors, Basel, v.16, n.8, p.1222, 2016.

SALVIANO, G.O.; MARTINS M.P.O.; DA SILVA A.U.; BORGES, E.F.; DOS REIS, E.F. Análise espacial de atributos físicos de solo do cerrado e produtividade do tomate industrial. In: CONGRESSO BRASILEIRO DE ENGENHARIA AGRÍCOLA, 47., 2018. Brasília, DF. Anais [...]. Jaboticabal: SBEA, 2018.

SANTOS, M. S.; GEBLER, L.; SEBEM, E. Proposição de metodologia para mapeamento e geoestatística na viticultura sobre sistema de condução de espaldeira baseado em um estudo de caso. In: CONGRESSO SULAMERICANO DE AGRICULTURADE PRECISÃO E MÁQUINAS PRECISAS, 5., 2019. Anais [...], NãoMeToque: Prefeitura Municipal de Não-Me-Toque, p.642-651, 2019.
SANTOS, T. T. Detecção automática de bagas de café em imagens de campo. In: CONGRESSO BRASILEIRO DE AGROINFORMÁTICA, 10., 2015, Ponta Grossa. Anais [...]. Ponta Grossa: Universidade Estadual de Ponta Grossa, 2015.

SANTOS, T. T.; BASSOI, L. H.; OLDONI, H.; MARTINS, R. L. Automatic grape bunch detection in vineyards based on affordable 3D phenotyping using a consumer webcam. In: CONGRESSO BRASILEIRO DE AGROINFORMÁTICA, 11., 2017, Campinas. Anais [...]. Campinas: Editora da Unicamp: Embrapa Informática Agropecuária, 2017.

SANTOS, T. T.; de SOUZA, L. L.; dos SANTOS, A. A.; AVILA, S. Grape detection, segmentation, and tracking using deep neural networks and three-dimensional association. Computers and Electronics in Agriculture, Amsterdam, v. 170, p. 105247, 2020.

SARRON, J.; MALÉZIEUX, É.; SANÉ, C.A.B.; FAYE, É. Mango yield mapping at the orchard scale based on tree structure and land cover assessed by UAV. Remote Sensing, Washington, v. 10, n. 12, p. 1900, 2018.

SCHMILDT, E.R.;ALEXANDRE, R.S.; SIQUEIRA, A.L.; MAYRINCK, L.G.; SCHMILDT, O. Dimensionamento amostral para analisar caracteres físicos e químicos de frutos de maracujá-fedorento. Revista Ceres, Viçosa, MG, v.64, n.2, p.115-121, 2017.

SHAFIEKHANI, A.; KADAM, S.; FRITSCHI, F.B.; DESOUZA, G.N. Vinobot and vinoculer: Two robotic platforms for high-throughput field phenotyping. Sensors, Basel, v. 17, n. 1, p. 214, 2017.

SILVA, F.S.; de ALMEIDA GOTTSCHALL, C.R.LIMA, D.S.; MARQUES, J.E.S.; AMADO, J.A.D. Desenvolvimento de um controle inteligente para seleção de mangas aplicada a um protótipo de manufatura robotizada. In: MOSTRA NACIONAL DE ROBÓTICA, Curitiba, 2017.

SILVA, M.D.S.; SILVA, S.D.O.; DONATO, S.; LEDO, C.D.S.; SAMPAIO FILHO, O.M.; SILVA, G.D. Tamanho da parcela experimental de mamoeiro pelo método da máxima curvatura modificado. In: SIMPÓSIO DO PAPAYA BRASILEIRO, 7.; 2018, Vitória. Anais [...]. Vitória: Papaya Brasil, 2018. 
SILVA, T.R. da; BELLO, T.B.; FERNANDES, P.L.B.G.; QUEIROZ, C.K. de; COSTA, A.G. Uso de imagens digitais como indicador de qualidade de tomates. In: CONGRESSO BRASILEIRO DE ENGENHARIA AGRÍCOLA-CONBEA, 46., 2017, Maceió. Anais [...], Jaboticabal: SBEA, 2017.

SINGH, A.; GANAPATHYSUBRAMANIAN, B.; SINGH, A.K.; SARKAR, S. Machine learning for highthroughput stress phenotyping in plants. Trends in Plant Science, Amsterdam, v.21, n.2, p.110-124, 2016.

SOUZA, C.G.; CARVALHO, L.;AGUIAR, P.;ARANTES, T.B. Algoritmos de aprendizagem de máquina e variáveis de sensoriamento remoto para o mapeamento da cafeicultura. Boletim de Ciências Geodésicas, Curitiba, v.22, n.4, p.751-773, 2016.

SRINIVASAN, A. Precision agriculture: an overview. In: SRINIVASAN, A. (ed.). Handbook of precision agriculture. Principles and applications. Boca Raton: CRC. Press, p.3-18, 2009.

STRUTHERS, R.; IVANOVA, A.; TITS, L.; SWENNEN, R.; COPPIN, P. Thermal infrared imaging of the temporal variability in stomatal conductance for fruit trees. International Journal of Applied Earth Observation and Geoinformation, Enschede, v.39, p.9-17, 2015.

UMBELINO, A.S. da; MARTINS, M.P. de O.; MASSOLA, M.P.; PINTO, H.S.; REIS, E.F. dos. Correlação espacial do teor de potássio no solo com a produtividade e qualidade do fruto de tomate industrial. In: CONGRESSO BRASILEIRO DE ENGENHARIA AGRÍCOLA CONBEA, 46., 2017, Maceió. Anais [...] Jaboticabal: SBEA, 2017.
VANBRABANT, Y.; TITS, L.; DELALIEUX, S.; PAULY, K.; VERJANS, W.; SOMERS, B. Multitemporal chlorophyll mapping in pome fruit orchards from remotely piloted aircraft systems. Remote Sensing, Washington, v.11, n.12, p.1468, 2019.

VIANA, L.A.; ZAMBOLIM, L.; SOUSA, T.V.; TOMAZ, D.C. Potencial uso de câmera termal acoplada a vant para monitoramento de culturas/potential use of thermal camera coupled in UAV for culture monitoring. Revista Brasileira de Engenharia de Biossistemas, Tupã, v.12, n.3, p.286-298, 2018.

VILLA-HENRIKSEN, A.; EDWARDS, G.T.; PESONEN, L.A.; GREEN, O.; SØRENSEN, C.A.G. Internet of Things in arable farming: Implementation, applications, challenges and potential. Biosystems Engineering, London, v.191, p.60-84, 2020.

ZHAO, T.; WANG, Z.; YANG, Q.; CHEN, Y. Melon yield prediction using small unmanned aerial vehicles. In: AUTONOMOUS AIR AND GROUND SENSING SYSTEMS FOR AGRICULTURAL OPTIMIZATION AND PHENOTYPING, 2., 2017, Anaheim. Proceedings [...]. Anaheim: International Society for Optics and Photonics, 2017.

ZUDE-SASSE, M.; FOUNTAS, S.; GEMTOS,. T.A.; ABU-KHALAF, N. Applications of precision agriculture in horticultural crops. European Journal of Horticultural Science, Sttugart, v.81, n.2, p.78-90, 2016. 